\title{
Prevalence of CYP17A1 gene mutations in 17a-hydroxylase deficiency in the Chinese Han population
}

\author{
Menglin Wang ${ }^{1}$, Hao Wang ${ }^{1 *}$ (D), Haiying Zhao ${ }^{1}$, Ling Li ${ }^{1}$, Min Liu', Fujia Liu², Fansen Meng ${ }^{1}$ and Caini Fan ${ }^{1}$
}

\begin{abstract}
Background: 17a-hydroxylase deficiency is a rare autosomal recessive disorder caused by mutations in the cytochrome P450 family 17 subfamily A member 1 gene. The major clinical presentation includes hypertension, hypokalemia, male pseudohermaphroditism and female gonadal dysplasia. Hundreds of pathogenic variants have been reported in this disorder, and some common mutations were found to be race-specific.

Case presentation: In this study, we reported 5 Chinese girls with 17a-hydroxylase deficiency from Henan Province. The patients all came to the hospital for hypertension, and they also presented with sexual infantilism. The average age of the patients was 14 years old, ranging from 12 to 17 years old. They all had reduced blood cortisol, estradiol (E2), and testosterone (TESTO) and increased adrenocorticotropic hormone (ACTH), follicle-stimulating hormone (FSH), and luteinizing hormone $(\mathrm{LH})$. They all had the appearance of females; however, three of the chromosome karyotypes were 46XX, and two were 46XY.

Conclusions: All of the patients carried a mutation on the 329 amino acid of CYP17A1 exon 6. By summarizing the currently known pathogenic mutations of 17a-hydroxylase deficiency, we demonstrated the prevalence of these gene mutations in Chinese Han and non-Chinese populations.
\end{abstract}

Keywords: 17a-hydroxylase deficiency, Congenital adrenal hyperplasia, Hypertension, CYP17A1, Gene mutation

\section{Background}

Congenital adrenal hyperplasia $(\mathrm{CAH})$ is a genetic disease caused by a deficiency of steroid hormone synthesis enzyme. $\mathrm{CAH}$ includes a group of autosomal recessive disease subtypes involving 21-hydroxylase deficiency [1],

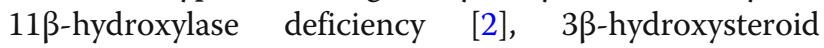
hydrogenase deficiency [3], 17 $\alpha$-hydroxylase deficiency (17 $\alpha-\mathrm{OHD})[4]$ and congenital lipoid adrenal hyperplasia (CLAH) [5]. 17 $\alpha-\mathrm{OHD}$ is a rare type of $\mathrm{CAH}$ and accounts for $1 \%$ of $\mathrm{CAH}[6,7] .17 \alpha-\mathrm{OHD}$ is caused by a mutation in the cytochrome P450 family 17 subfamily A member 1 (CYP17A1) gene, which encodes $17 \alpha$-hydroxylase, which leads to an imbalance of adrenal cortex and sex gland hormones and therefore low plasma cortisol and sexual hormone as well as high adrenocorticotropic hormone (ACTH). Clinically, $17 \alpha-\mathrm{OHD}$ is characterized by

\footnotetext{
* Correspondence: doctorwanghao@126.com

'Department of Hypertension, Henan Provincial People's Hospital; People's

Hospital of Zhengzhou University, Zhengzhou 450003, Henan, China

Full list of author information is available at the end of the article
}

hypertension, hypokalemia, male pseudohermaphroditism and female gonadal dysplasia. The diagnosis of $17 \alpha-\mathrm{OHD}$ is based on a comprehensive overview of clinical, biochemical and molecular features. However, the clinical and biochemical presentations of this disorder are highly variable, and $10-15 \%$ of patients are normotensive at diagnosis [8]. Therefore, genetic diagnosis is crucial for diagnostic confirmation. Here, we reported five $17 \alpha-\mathrm{OHD}$ teenagers presenting in our hospital within the past 4 years whose diagnoses were all confirmed via genetic testing. Surprisingly, genetic testing also revealed their molecular generality and hence implied similar molecular pathogenesis. We also summarized the $17 \alpha-\mathrm{OHD}$-causing mutations and described mutations common in the Chinese population, which demonstrated race-dependent differences.

\section{Case presentation}

\section{The details of patient hospitalization}

From October 2013 to December 2017, five female teenagers (social gender) with hypertension were hospitalized 
in the Hypertension Department of Henan Provincial People's Hospital and received a final diagnosis of $17 \alpha-$ OHD. The average age of the patients was 14 years, with a range from 12 to 17 years old.

Patient 1, a 17-year-old female, was hospitalized because of a headache and giddy feelings lasting for 2 months and hypertension for 1 month. Her average daytime systolic blood pressure was $134 \mathrm{mmHg}$, her diastolic blood pressure was $96 \mathrm{mmHg}$, and her heart rate was 86 beats per minute. She had a normal BMI but had immature breasts and vulva and no menstruation, hirci or pubic hair. Hormone testing showed decreased plasma estradiol (E2), testosterone (TESTO) and renin activity but increased progesterone (PROG), follicle-stimulating hormone (FSH), luteinizing hormone (LH), aldosterone and aldosteronerenin ratio (ARR) (Table 1). She had reduced blood cortisol and increased ACTH. Further examination indicated that she had hypertension fundus changes, and her urine microalbuminuria test was more than $150 \mathrm{mg} / \mathrm{l}$. Pelvic magnetic resonance imaging (MRI) did not detect the uterus or ovaries. Her chromosome karyotype was 46XY.

Patient 2 was a 14-year-old girl who was hospitalized because of hypertension lasting for 2 months. Her hypertension was also found in a school physical examination. Her average daytime blood pressure was $169 / 136 \mathrm{mmHg}$, and her heart rate was $83 \mathrm{bpm}$. She had normal BMI but immature breasts and vulva and had not experienced menstruation. Blood potassium was $3.52 \mathrm{mmol} / \mathrm{l}$, which was on the low threshold. The hormone test indicated a disorder with decreased plasma E2, TESTO and renin activity but increased PROG, FSH, LH, aldosterone and ARR. She had reduced blood cortisol and increased ACTH (Table 1). Pelvic MRI showed an immature uterus and ovaries. Her chromosome karyotype was 46XX.

Patient 3 was a 13-year-old female who was hospitalized because of hypertension accompanied by headache lasting for 2 months. She was found to have high blood pressure at a school physical examination. Her average daytime blood pressure was 158/105 $\mathrm{mmHg}$, and her heart rate was $85 \mathrm{bpm}$. Blood potassium was slightly lower than the normal value of $3.32 \mathrm{mmol} / \mathrm{l}$. She had normal BMI but immature breasts and vulva and had not experienced menstruation. Her plasma E2, TESTO and renin activity were all decreased, whereas her PROG, FSH, LH, aldosterone and ARR were increased. Her blood cortisol was reduced, and ACTH was increased. She had hypertension fundus changes, and the result of the urine microalbuminuria test was $439.9 \mathrm{mg} / \mathrm{l}$, which suggested that she had hypertension complications. Pelvic MRI displayed her immature uterus and ovaries. Her chromosome karyotype was 46XX.

Patient 4, who had the appearance of a 12-year-old girl, was hospitalized because she had felt dizzy for 1 week. Her average daytime blood pressure was $165 / 120 \mathrm{mmHg}$, and her heart rate was $90 \mathrm{bpm}$. Blood potassium was extremely low, with a value of $2.96 \mathrm{mmol} / \mathrm{l}$. She had a normal BMI but immature breasts and vulva and had not experienced menstruation. Hormone analysis showed that she had hormone disorder with reduced plasma E2, TESTO and renin activity but enhanced PROG, FSH, LH, aldosterone and ARR (Table 1). She had reduced blood cortisol, and ACTH was extremely high. Pelvic MRI could not find her uterus and ovaries but showed suspected testis. Her chromosome karyotype was 46XY.

Patient 5 was a 13-year-old girl who was hospitalized because of high blood pressure lasting for 2 months. Her average daytime blood pressure was $187 / 127 \mathrm{mmHg}$, and her heart rate was $76 \mathrm{bpm}$. Blood potassium was extremely low, with a value of $2.7 \mathrm{mmol} / \mathrm{l}$. She had a normal BMI but immature breasts and vulva and had not experienced menstruation. Her plasma E2, TESTO and renin activity were all decreased, whereas PROG, FSH, LH, aldosterone and ARR were increased (Table 1). She had reduced blood cortisol and increased ACTH. Pelvic MRI showed an immature uterus and ovaries, and her chromosome karyotype was 46XX.

\section{Patient follow-up after treatment}

Patient 1 was indicated to be a male according to the karyotype, but testicles were not found by imaging. Hence, he received intraperitoneal exploration, and cryptorchidism was found in his abdomen. Since cryptorchidism could have a malignant transformation, he was advised to undergo cryptorchidectomy. However, he was still hesitant. His blood pressure was well controlled by a calcium antagonist, spironolactone and cortisone. The main clinical features and biochemical and hormonal findings are summarized in Table 1.

Patient 4 was also found to be male by karyotype. However, he decided to be a female and underwent cryptorchidectomy. Medications including cortisone, estradiol, calcium carbonate D3 and alfacalcidol were used to maintain normal development.

Patients 2, 3 and 5 were confirmed to be female and directly given exogenous estrogens, including estradiol and progesterone, to maintain proper development of their genitals. At the same time, calcium antagonists, angiotensin II receptor blockers, spironolactone, calcium carbonate D3 and cortisone were used to control blood pressure. During follow-up, their blood pressure had decreased to normal, and the immature uterus and breasts had started to develop. Patient 5 also had normal menstruation (Additional file 1).

\section{CYP17A1 gene sequence analysis}

The entire coding region of the patient's CYP17A1 gene, including the exon-intron boundaries, was sequenced. Pathogenic mutations were found in the CYP17A1 gene 
Table 1 Clinical characteristics of five 17a-hydroxylase deficiency cases. Serum cortisol, ACTH, FSH, LH, testosterone, estradiol and progesterone were measured using chemiluminescent immunoassays. Plasma renin activity and aldosterone were determined by the radio-immunity method

\begin{tabular}{|c|c|c|c|c|c|c|}
\hline Clinical information & Patient 1 & Patient 2 & Patient 3 & Patient 4 & Patient 5 & Normal value \\
\hline Age (years old) & 15 & 14 & 13 & 12 & 13 & \\
\hline Social Gender & Female & Female & Female & Female & Female & \\
\hline $\begin{array}{l}\text { Blood pressure } \\
(\mathrm{mmHg})\end{array}$ & $134 / 96$ & $169 / 136$ & $158 / 105$ & $165 / 120$ & $187 / 127$ & \\
\hline $\begin{array}{l}\text { Blood potassium } \\
(\mathrm{mmol} / \mathrm{l})\end{array}$ & 4.29 & 3.52 & 3.32 & 2.96 & 2.7 & $3.5-5.5 \mathrm{mmol} / \mathrm{l}$ \\
\hline $\begin{array}{l}\text { Plasma renin } \\
\text { activity(laying) }\end{array}$ & 0.2 & 0.2 & NA & 0.2 & 0.2 & $0.15-2.33($ ng.ml)/h \\
\hline $\begin{array}{l}\text { Plasma renin activity } \\
\text { (standing) }\end{array}$ & 0.2 & 0.2 & 0.2 & 0.2 & 0.2 & $0.1-6.56(\mathrm{ng} / \mathrm{ml}) / \mathrm{h}$ \\
\hline Aldosterone(laying) & 79.9 & 103 & NA & 111 & 127 & $30-160 \mathrm{pg} / \mathrm{ml}$ \\
\hline Aldosterone (standing) & 68.1 & 108 & 81.4 & 133 & 158 & $70-300 \mathrm{pg} / \mathrm{ml}$ \\
\hline ARR & 34.05 & 54 & 40.7 & 66.5 & 79 & \\
\hline Angiotensinll (laying) & 34.3 & 44.9 & NA & 39.6 & 87.2 & $30-160 \mathrm{pg} / \mathrm{ml}$ \\
\hline $\begin{array}{l}\text { Angiotensinll } \\
\text { (standing) }\end{array}$ & 50.9 & 51.9 & 50.2 & 51.6 & 96.3 & $70-300 \mathrm{pg} / \mathrm{ml}$ \\
\hline Blood cortisol (0 am) & 0 & 0.01 & 0.01 & 0.3 & NA & 0 \\
\hline Blood cortisol (8 am) & 0.32 & 0.3 & 0.01 & 0.6 & 0.033 & $6.7-22.6 \mu \mathrm{g} / \mathrm{dl}$ \\
\hline Blood cortisol (4 pm) & 0.04 & 0.19 & 0.11 & 0.4 & 0.015 & $3.35-11.3 \mu \mathrm{g} / \mathrm{dl}$ \\
\hline Blood ACTH (0 am) & 16.2 & 12.4 & 13.7 & 41.1 & NA & $\mathrm{pg} / \mathrm{ml}$ \\
\hline Blood ACTH (8 am) & 90.1 & 84.5 & 33.6 & 373 & 168.5 & $12-46 \mathrm{pg} / \mathrm{ml}$ \\
\hline Blood ACTH (4Pm) & 16.2 & 12.4 & 13.7 & 41.1 & 86.9 & $6-23 \mathrm{pg} / \mathrm{ml}$ \\
\hline E2 & 12.19 & 9.36 & 0.01 & 17.1 & 4.14 & $\begin{array}{l}\text { Children:male0-41 IU/L, } \\
\text { female0-50 IU/L }\end{array}$ \\
\hline PROG & 11.4 & 14.25 & 7.43 & 13.46 & 10.55 & $0-1.2 \mathrm{IU} / \mathrm{L}$ \\
\hline TESTO & 0.25 & 0.24 & 0.1 & 0.17 & 0.01 & $\begin{array}{l}\text { Children:male0.45-2.26 IU/L, } \\
\text { female0.03-1 IU/L }\end{array}$ \\
\hline $\mathrm{FSH}$ & 69.06 & 67.76 & 76.86 & 31.53 & 117.27 & $\begin{array}{l}\text { Children:male0-10 IU/L; } \\
\text { femal0-15 IU/L }\end{array}$ \\
\hline $\mathrm{LH}$ & 26.42 & 29.81 & 26.25 & 10.14 & 59.38 & $\begin{array}{l}\text { Children:male0-12 IU/L, } \\
\text { female0-15 IU/L }\end{array}$ \\
\hline T3 & 5.68 & 5.87 & 5.49 & 7.22 & NA & $3.5-6.5 \mathrm{pmol} / \mathrm{l}$ \\
\hline $\mathrm{T} 4$ & 15.6 & 17.53 & 16.46 & 19.44 & NA & $11.5-22.7 \mathrm{pmol} / \mathrm{l}$ \\
\hline TSH & 1.846 & 1.946 & 3.447 & 1.033 & NA & $0.55-4.78 \mathrm{ulU} / \mathrm{ml}$ \\
\hline $\begin{array}{l}\text { Urine } \\
\text { microalbuminuria(mg/l) }\end{array}$ & $>150$ & 12.87 & 439.19 & NA & NA & $<150 \mathrm{mg} / \mathrm{l}$ \\
\hline Urine protein & + & - & NA & + & NA & \\
\hline Urine protein(24 h) & 0.1 & NA & NA & NA & NA & $0-1.5 \mathrm{~g} / 24 \mathrm{~h}$ \\
\hline $\begin{array}{l}\text { Hypertension Fundus } \\
\text { changes }\end{array}$ & Positive & Negative & Positive & Negative & NA & \\
\hline $\begin{array}{l}\text { Chromosome } \\
\text { karyotype }\end{array}$ & $46 X Y$ & $46 X X$ & $46 X X$ & $46 X Y$ & $46 X X$ & \\
\hline SRY & Positive & Negative & Negative & Positive & Negative & \\
\hline Pelvic MRI & $\begin{array}{l}\text { No uterus and } \\
\text { ovaries }\end{array}$ & $\begin{array}{l}\text { uterus and } \\
\text { ovaries }\end{array}$ & $\begin{array}{l}\text { uterus and } \\
\text { ovaries }\end{array}$ & $\begin{array}{l}\text { No uterus } \\
\text { and ovaries }\end{array}$ & $\begin{array}{l}\text { uterus and } \\
\text { ovaries }\end{array}$ & \\
\hline mutation & $\begin{array}{l}\text { c.985_ } \\
\text { 987delinsAA }\end{array}$ & $\begin{array}{l}\text { c.987delC } \\
\text { p.Y329 }\end{array}$ & $\begin{array}{l}\text { c.985_987delinsAA } \\
\text { (p.Y329Kfs) }\end{array}$ & $\begin{array}{l}\text { c.985_987delinsAA } \\
\text { (p.Y329Kfs) }\end{array}$ & $\begin{array}{l}\text { c.985_987delinsAA } \\
\text { (p.Y329Kfs) }\end{array}$ & \\
\hline
\end{tabular}


Table 1 Clinical characteristics of five 17a-hydroxylase deficiency cases. Serum cortisol, ACTH, FSH, LH, testosterone, estradiol and progesterone were measured using chemiluminescent immunoassays. Plasma renin activity and aldosterone were determined by the radio-immunity method (Continued)

\begin{tabular}{|c|c|c|c|c|c|c|}
\hline Clinical information & Patient 1 & Patient 2 & Patient 3 & Patient 4 & Patient 5 & Normal value \\
\hline & $\begin{array}{l}\text { (p.Y329Kfs) } \\
\text { c.1459_1467 } \\
\text { (p.487_489del) }\end{array}$ & & & & & \\
\hline homozygote & heterozygote & homozygote & homozygote & homozygote & heterozygote & \\
\hline
\end{tabular}

NA not available, E2 estradiol, TESTO testosterone, PROG Progesteron

in all five patients. Patient 1 carried two variants of the CYP17A1 gene: the nonsense mutation c.985_987delinsAA (p. Y329Kfs) het and missing mutation c.1459_1467 (p.487_489del) het. Both CYP17A1 c.985_987delinsAA and c.1459_1467 (p.487_489del) had no frequency record in the 1000 Genomes Project (1000G) and ESP6500 databases, whereas they showed a very low frequency $(1.291 \times$ $10^{-5}$ and $4.947 \times 10^{-5}$ ) in Exome Aggregation Consortium (ExAC), and they were confirmed to be class $\mathrm{A} \mathrm{mu-}$ tations according to the American College of Medical
Genetics (ACMG) standard. These two mutations were verified in her parents. Her father carried c.1459 1467 (p.487_489del) het, and her mother had c.985_987delinsAA (p. Y329Kfs) het (Fig. 1). Interestingly, we found that the other four patients also carried the mutation in the 985-987 region. Patient 5 was heterozygous, and patients 3 and 4 were homozygous for c.985_987delinsAA(p.Y329Kfs), whereas patient 2 was homozygous for c.987delC p.Y329*. The detailed pedigrees of these five families are shown in Fig. 1 and Table 1.

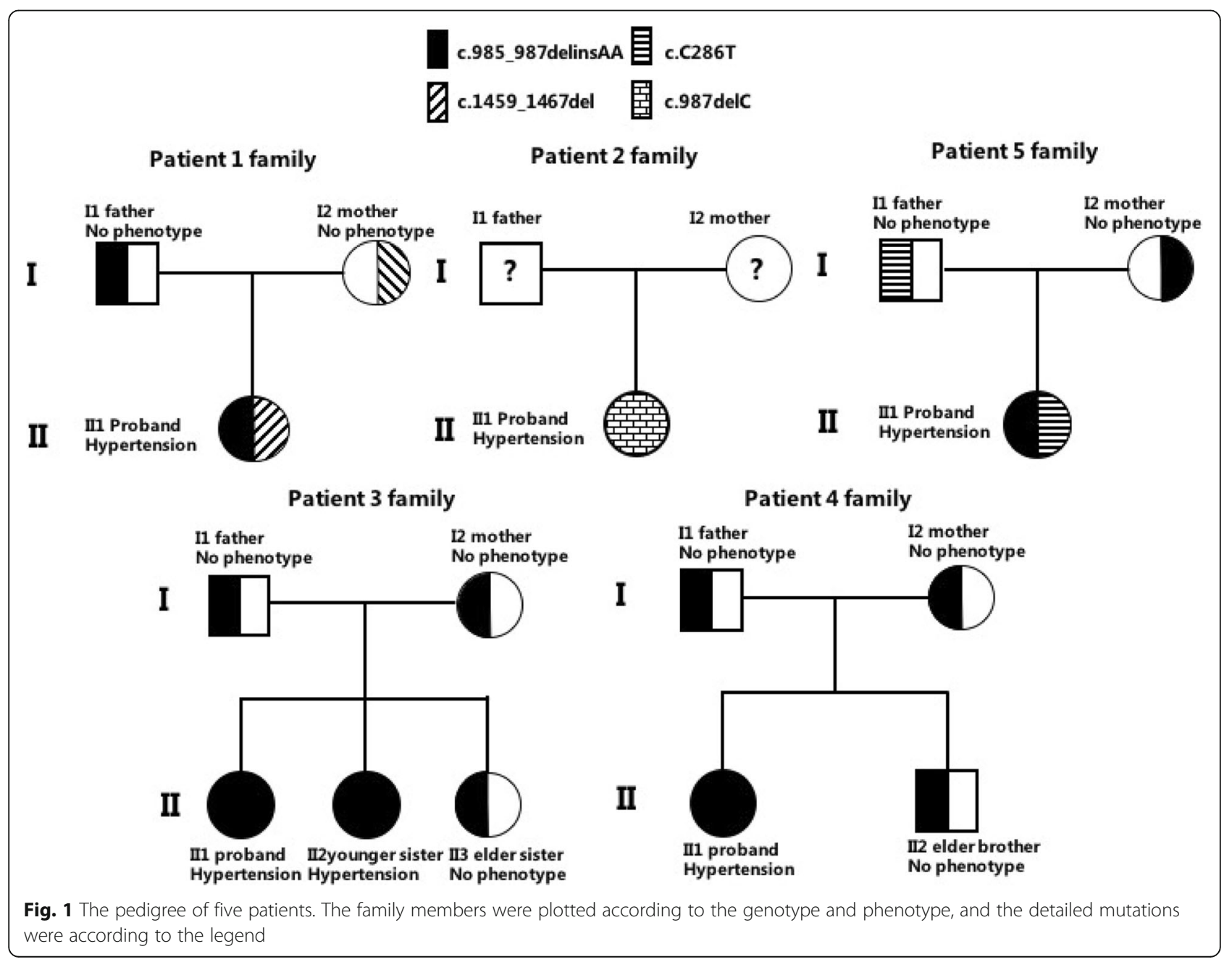




\section{D protein conformation}

We mimicked the three-dimensional structure of human $17 \alpha$-hydroxylase protein before and after CYP17A1 mutation. PROCHECK software was used to evaluate the model's reliability. It was reliable, with $83.4 \%$ amino acid residues in most favored regions, and $16 \%$ in additional allowed regions (Additional file 2: Figures S1\&S2).

According to the three-dimensional protein model, tyrosine 329 (Tyr329) was located in the center of the Jhelix of $17 \alpha$-hydroxylase and formed a hydrophobic portion interacting with the C terminal L460 of the L helix to stabilize the enzymatic structure (Fig. 2a). However, the replacement of Tyr329 by lysine (Lys) led to the loss of 418-503 amino acids, which directly damaged the enzyme active center (Fig. 2b).

Furthermore, we know that the heme binding site (435-455aa) is a pivotal functional region of $17 \alpha$-hydroxylase, in which Arg440 and heme formed 2 hydrogen bonds and Pro434 and Phe453 were essential in stabilizing the $\beta$-fold and J-helix structure around the active center, respectively (Fig. 3a). Nevertheless, the Tyr329Lys mutation caused a shortened protein missing the amino acids after 417, which brought about the loss of the heme binding region (435-455aa) and therefore $17 \alpha$-hydroxylase functional deficiency. (Fig. 3b).

\section{Discussion and conclusions}

The first $17 \alpha-O H D$ case was reported in 1966 by Biglieri et al. [9], and it involved a 35-year-old female with the initial symptom of hypertension, who was short in stature and had delayed menses. Subsequently, New et al described a male $17 \alpha-\mathrm{OHD}$ case characterized by male pseudohermaphroditism, ambiguous external genitalia, and the absence of male secondary sexual characteristics in 1970 [10]. The first Chinese case was described by Shanghai Rui Jin Hospital in 1982 [11]. To date, more than 500 cases have been reported.

Loss of function of $17 \alpha$-hydroxylase caused by the CYP17A1 mutation could explain the whole $17 \alpha-\mathrm{OHD}$ pathogenesis. 17 $\alpha$-hydroxylase is the key enzyme that regulates hormone synthesis in the adrenal gland and gonads. It is composed of 504 amino acids and is a mixed functional enzyme with the combined activity of both $17 \alpha$-hydroxylase and 17, 20-lyase [6] (Fig. 4). 17 $\alpha$ hydroxylase is mainly located in the testis Leydig cells, follicular ovarian cells, and the zona fasciculata and zona reticularis of the adrenal grand but not the zona glomerulosa. Catalyzed by $17 \alpha$-hydroxylase, pregnenolone and progesterone are transformed into $17-\mathrm{OH}$ pregnenolone and progesterone, respectively, which are further cleaved by 17,20-lyase to form the precursors of estrogen, dehydroepiandrosterone (DHEA) and androstenedione (ASD) [12]. In the adrenal gland, 21 - and $17 \alpha$-hydroxylase hydroxylates progesterone to produce deoxycorticosterone (DOC) and 11-deoxycortisol and finally mineralocorticoid and hydrocortisone, respectively. Conversely, deficiency of $17 \alpha$-hydroxylase causes the accumulation of corticosterone and aldosterone, which brings about hypertension and hypopotassemia. At the same time, deficiency of $17 \alpha$-hydroxylase also leads to cortisol and sexual hormone disorder and, consequently, the symptoms of male pseudohermaphroditism and female
A

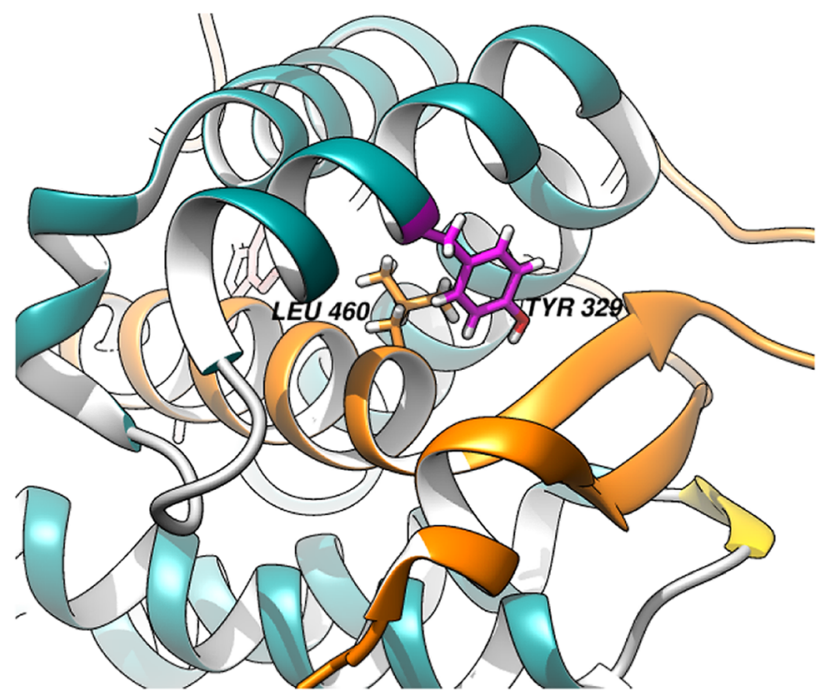

B

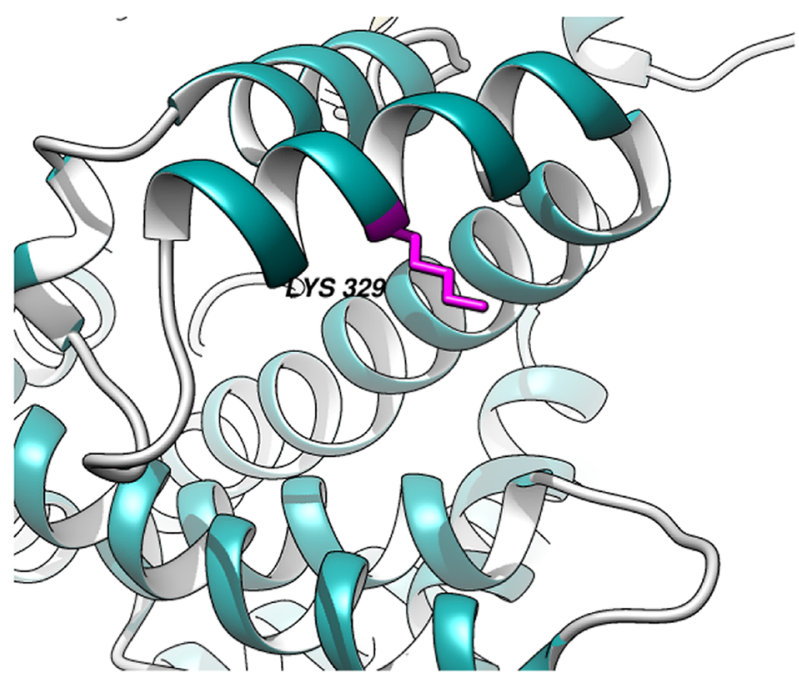

Fig. 2 The CYP17A1 protein active center before $(\mathbf{a})$ and after $(\mathbf{b})$ amino acid changes. The CYP17A1 protein 3D model was mimicked by a computer. a Normal protein active center of 3D structure. The Van der Waals force between Tyr329 and Leu460 stabilized the protein active center. The region highlighted in orange was the missing part after mutation. $\mathbf{b}$ Mutated protein active center of 3D structure. The replacement of Tyr329 by Lys329 caused the loss of protein active center stability 

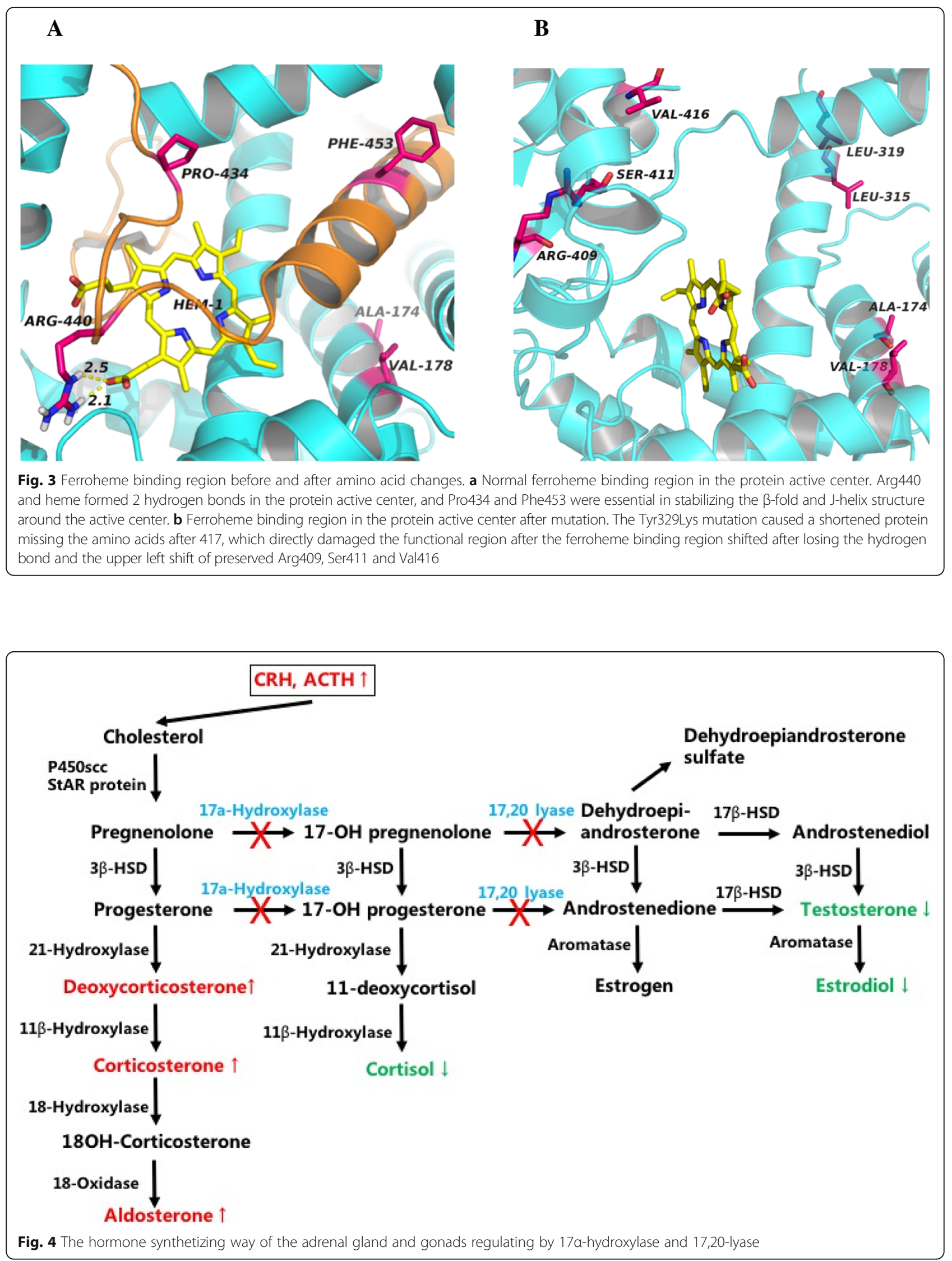
gonadal dysplasia. As feedback to the reduced cortisol synthesis, the pituitary could excrete excess ACTH, which may lead to bilateral adrenocorticohyperplasia.

$17 \alpha$-hydroxylase is encoded by the CYP17A1 gene, which was first cloned in 1987 [13]. It is located on chromosome 10q24-25 and is composed of 8 exons and 7 introns, with a total length of $5.7 \mathrm{~kb}[14,15]$. To date, 119 mutations in exons and introns have been considered pathogenic or disease-causing mutations (DM) in $17 \alpha-O H D$ according to the ClinVar and HGMD databases, including missense mutations, insertions, deletions and duplications, and frameshift (fs) mutations (Additional file 2: Table S1). Among the five patients we reported here, patients one and five carried compound heterozygous mutations, whereas all the others had homozygous mutations. Surprisingly, all five patients carried the mutation encoding the same protein position tyrosine-329 with c.987delC in patient 3 and c.985 987delinsAA in other patients. The nucleotide 985 to 987 (TAC) of CYP17A1 was replaced by AA in exon 6 via $985 \mathrm{~T}>\mathrm{C}$ and $987 \mathrm{delC}$ to form a deletion/insertion mutation, causing a frameshift with tyrosine (Y)-329Lysine $(\mathrm{K})$ as the first affected amino acid. This event finally led to the premature stop codon of 418TGA and the formation of a shortened protein with 417 amino acids without the pivotal functional domain - the hemebinding region (435-455aa). The c.985_987delinsAA (p.Y329K) mutation in CYP17A1 causes complete loss of $17 \alpha$-hydroxylase activity in vivo and produces low-density metabolic products in vitro [16].

This mutation was initially reported by a Korean group as a compound heterozygote in a Korean individual with primary amenorrhea, hypokalemic, hypertension and karyotype 46 XX [17] in 2003. This mutation was widely detected in Chinese 17 $\alpha$-OHD patients [18, 19]. According to their observation, Tian et al. assumed that mutations of $17 \alpha-\mathrm{OHD}$ varied according to race and that the c.985_987delinsAA mutation was common in Asian people [20]. A study of 15 Chinese $17 \alpha-O H D$ patients reported that 10 out of $15(66.7 \%)$ patients carried the c.985_987delinsAA (p.Y329K) mutation, with two homozygotes and 8 heterozygotes [21]. To explain the high prevalence of the c.985_987delinsAA (p. Y329K) mutation, a possible founder effect of this mutation has been described [22]. However, the prevalence of $17 \alpha-\mathrm{OHD}$ mutations in China remains elusive. Han et al indicated that approximately $90 \%$ of $17 \alpha-\mathrm{OHD}$ patients carried at least one of the mutations (c.985_987delinsAA (p.Y329K); c.1459_1467 (p.487_489del)) [16]. To clarify this, we searched all published $17 \alpha-\mathrm{OHD}$ English papers from PubMed and summarized the CYP17A1 gene mutations of all reported cases. A total of 133 English papers introduced $17 \alpha-\mathrm{OHD}$ cases, and 111 of these studies performed genetic testing. In total, genetic mutations were reported in 181 Chinese cases, of which 70 (38.6\%) had c.985_987delinsAA (p.Y329K), 55 (30.4\%) had c.1459_ 1467del (p.487_489del) mutations, and the remaining 43 (31\%) had other mutations. In contrast, $92.7 \%$ of cases (231 out of 249 cases) carried mutations other than c. 985 987delinsAA (p.Y329K) and c.1459_1467 (p.487_489del) in non-Chinese individuals. Only 18 cases carried 329 amino acid mutations: 8 Korean (3.2\%) patients out of 249 non-Chinese patients carried the c.985_987delinsAA (p.Y329K), 1 Japanese (0.4\%) patient carried Y329X iA [23], 3 Brazilian (1.2\%) patients had Y329D [24], and 6 Brazilian patients had Y329X [7]. The prevalence of Chinese $17 \alpha$-OHD mutations is shown in Fig. 5.

To further understand how the gene mutation influenced the protein $3 \mathrm{D}$ conformation, we mimicked the protein 3D structure of $17 \alpha$-hydroxylase by computer. The 3D conformation of $17 \alpha$-hydroxylase has been reported in a previous study, which showed that the replacement of tyrosine 329 with a charged aspartate weakened the hydrophobic interaction and destabilized the enzymatic structure but did not directly perturb the active site [7]. Here, we first created a $17 \alpha$-hydroxylase protein 3D model and mimicked the replacement of tyrosine 329 with lysine. The heme binding site (435-455aa) is a pivotal functional region of $17 \alpha$-hydroxylase. Arg440 and heme formed 2 hydrogen bonds, and Pro434 and Phe453 stabilized the $\beta$-fold and J-helix structures around the active center, respectively (Fig. 3a). The replacement of Tyr329 by lysine (Lys) caused the loss of 418-453 amino acids, directly damaging the heme binding site, the enzymatic active center (Fig. 3b). Hence, the c.985_987delinsAA mutation was powerful enough to damage the functional heme region of $17 \alpha$-hydroxylase and consequently led to the loss or reduction of $17 \alpha$-hydroxylase activity.

In our study, all patients demonstrated clinical characteristics of $17 \alpha-\mathrm{OHD}$, including hypertension and secondary sexual disorder. Hypokalemia was found in four patients, and one patient had normal blood potassium. All five cases were teenagers who had exhibited hypertension symptoms approximately 8 weeks before hospitalization. However, patients 1 and 3 already had urine microalbuminuria and decreased circadian variation in blood pressure; specifically, patient 1's blood pressure changed to the reverse spoon shape, implying that their blood pressure could be abnormal far beyond the duration of observed symptoms. Compared to adults, the teenagers were too young and experienced more severe hypertension-related complications. Hence, the early identification and diagnosis of young patients could contribute to well-controlled blood pressure and reduce subsequent disease-related complications.

All five cases presented as females when hospitalized, but patients 1 and 4 were identified as males with $46 \mathrm{XY}$ after karyotype examination. It was hard for these patients to accept the fact that they were actually not girls, 


\begin{tabular}{|c|c|c|c|c|c|c|c|}
\hline & & & & & \multicolumn{3}{|l|}{ 972dupG } \\
\hline & & & & & \multicolumn{3}{|l|}{ 979_981del } \\
\hline & & & & & \multirow{2}{*}{\multicolumn{3}{|c|}{$\begin{array}{l}\text { 985delT } \\
987 \mathrm{C}>\mathrm{G}\end{array}$}} \\
\hline & & & & & & & \\
\hline & & & & & \multicolumn{2}{|l|}{$987 \mathrm{C}>\mathrm{A}$} & $1246 \mathrm{C}>\mathrm{T}$ \\
\hline & & & & & \multicolumn{2}{|l|}{ 987delC } & $1263 \mathrm{G}>\mathrm{A}^{\star}$ \\
\hline & $298-1 \mathrm{G}>\mathrm{A}^{\star}$ & & & & \multicolumn{2}{|l|}{ 1080_1081delinsA } & $1283 \mathrm{C}>\mathrm{T}$ \\
\hline & 302delC & & & & \multicolumn{2}{|l|}{$1085 \mathrm{G}>\mathrm{A}$} & $1301 C>T$ \\
\hline 186delC & $316 \mathrm{~T}>\mathrm{C}$ & & & & \multicolumn{2}{|l|}{$1096 \mathrm{G}>\mathrm{A}$} & $1306 \mathrm{G}>\mathrm{A}$ \\
\hline $245 \mathrm{C}>\mathrm{A}$ & 350_351del & & \multirow{2}{*}{\multicolumn{2}{|c|}{$667-13 \_667$}} & \multicolumn{2}{|l|}{$11117 C>T$} & $1324 \mathrm{~T}>\mathrm{C}$ \\
\hline $297+2 T>C^{*}$ & $373 \mathrm{C}>\mathrm{T}$ & & & & \multicolumn{2}{|l|}{ 985_987delinsAA } & $1358 \mathrm{~T}>\mathrm{C}$ \\
\hline 160_162del & $374 \mathrm{G}>\mathrm{A}$ & & -10 del & 775_776del & $1072 \mathrm{C}>\mathrm{T}$ & $1193 C>T$ & $1345 \mathrm{C}>\mathrm{T}$ \\
\hline $287 \mathrm{G}>\mathrm{A}$ & 431_433del & & $707 \mathrm{~T}>\mathrm{G}$ & $796 \mathrm{C}>\mathrm{G}$ & $1073 \mathrm{G}>\mathrm{A}$ & $1226 \mathrm{C}>\mathrm{G}$ & $1386 \mathrm{G}>\mathrm{T}$ \\
\hline $2 \mathrm{~T}>\mathrm{C}$ & 353_359dup & & $716 \mathrm{G}>\mathrm{A}$ & $916 A>G$ & $1118 \mathrm{~A}>\mathrm{T}$ & 1148delA & 1459_1467del \\
\hline $3 \mathrm{G}>\mathrm{C}$ & 393delC & $626 \mathrm{~T}>\mathrm{C}$ & 728delT & 932_939del & 1053_1055del & $1217 \mathrm{G}>\mathrm{T}$ & 1480_1487delinsCT \\
\hline $51 \mathrm{G}>\mathrm{A}$ & $436+5 G>T^{*}$ & $601 \mathrm{~T}>\mathrm{A}$ & 741delT & 900_901del & $1117 \mathrm{C}>\mathrm{A}$ & $1243+5 \mathrm{G}>\mathrm{A}^{*}$ & 1466delT \\
\hline $62 \mathrm{G}>\mathrm{A}$ & 327dupT & $437-2 \mathrm{~A}>\mathrm{C}^{*}$ & $683 \mathrm{C}>\mathrm{T} \#$ & $863 \mathrm{C}>\mathrm{A}$ & $985 \mathrm{~T}>\mathrm{G}$ & $1162 \mathrm{~A}>\mathrm{T}$ & $\underline{1247 G>A}$ \\
\hline $81 \mathrm{C}>\mathrm{A}$ & $328 \mathrm{~A}>\mathrm{T}$ & $521 \mathrm{C}>\mathrm{A}$ & $715 \mathrm{C}>\mathrm{T}$ & $896 \mathrm{~T}>\mathrm{A}$ & 986dupA & $1216 \mathrm{~T}>\mathrm{C}$ & 1313delG \\
\hline $103 \mathrm{C}>\mathrm{A}$ & $331 \mathrm{G}>\mathrm{A}$ & $529 \mathrm{~A}>\mathrm{G}$ & $753+1 \mathbf{G}>\mathbf{A}^{*}$ & $904 \mathrm{G}>\mathrm{C}$ & 991_993del & $1226 \mathrm{C}>\mathrm{T}$ & $1318 \mathrm{C}>\mathrm{T}$ \\
\hline $107 \mathrm{delT}$ & 334_336dup & $533 \mathrm{~T}>\mathrm{A}$ & & $914 \mathrm{~A}>\mathrm{G}$ & $995 \mathrm{~T}>\mathrm{C}$ & & $1319 \mathrm{G}>\mathrm{A}$ \\
\hline 177dupA & $340 \mathrm{~T}>\mathrm{G}$ & $580 \mathrm{G}>\mathrm{T}$ & & 938G $>A$ & $1024 \mathrm{C}>\mathrm{A}$ & & $1321 \mathrm{~T}>\mathrm{C}$ \\
\hline $191 \mathrm{~A}>\mathrm{C}$ & $347 \mathrm{~A}>\mathrm{T}$ & & & 930-954dup & $1039 \mathrm{C}>\mathrm{T}$ & & $1381 C>T$ \\
\hline 198delT\# & $361 \mathrm{~T}>\mathrm{C}$ & & & & $1040 \mathrm{G}>\mathrm{A}$ & & $1394 \mathrm{~T}>\mathrm{C}$ \\
\hline 204_228del & $362 \mathrm{G}>\mathrm{A}$ & & & & $1063 \mathrm{G}>\mathrm{A}$ & & 1435 1438dup \\
\hline 208_232del & & & & & $1084 \mathrm{C}>\mathrm{T}$ & & $\underline{1486 \mathrm{C}>\mathrm{T}}$ \\
\hline $269 \mathrm{G}>\mathrm{A}$ & & & & & $1117 \mathrm{C}>\mathrm{G}$ & & $\underline{1487 \mathrm{G}>A}$ \\
\hline \multicolumn{8}{|l|}{$278 \mathrm{~T}>\mathrm{G}$} \\
\hline \multicolumn{8}{|l|}{$286 \mathrm{C}>\mathrm{T}$} \\
\hline Exon1 & Exon 2 & Exon3 & Exon 4 & Exon5 & Exon6 & Exon7 & Exon8 \\
\hline \multicolumn{8}{|c|}{$\begin{array}{l}\text { Fig. } 5 \text { The 17a-OHD mutations in Chinese, Asian and other races. Red indicates Chinese; green indicates Asian; blue denotes mutations in both } \\
\text { Chinese and Asian populations; Black indicates non-Chinese and non-Asian populations. Note: \# means DM?; *indicates splicing mutation; del, } \\
\text { deletions; dup, insertions/duplication; delins, indels; the following mutations were carried but not mapped in the figure due to restricted space: } \\
\text { gross deletions: exons 1-6, c.(?_-345)_1039+?del; exons 1-6, c.(?_-172)_(1139+1_1140-1)del. Complex rearrangements: exons 1-6, del. c.- } \\
\text { 2011_436+ } 119 \text { and del c.437-93_1140-262; exons 2-3, del. } 518 \text { bp affecting parts of ex. 2-3, ins. } 469 \text { bp }\end{array}$} \\
\hline
\end{tabular}

and they had to decide their gender since it would influence ongoing therapy. Patient 1 was severely troubled by gender selection and determined to delay cryptorchidectomy. However, he could be in danger of malignant transformation of testosterone by postponing the surgery. Early identification and diagnoses of $17 \alpha-\mathrm{OHD}$ patients could resolve problems with gender selection earlier. Due to the variable clinical and biochemical presentations of this disorder, genetic tests, especially high frequency variant screening for c.985_987delinsAA (p.Y329K) and c.1459_ 1467 (p.487_489del), for example, could be helpful for the early identification of $17 \alpha-\mathrm{OHD}$ patients.

In summary, we reported five patients with $17 \alpha-\mathrm{OHD}$, first mimicked the 3D protein model of $17 \alpha$-hydroxylase after c.985_987delinsAA (p.Y329K) mutation and showed the damaged enzymatic active center after mutation. We first systematically summarized the currently known pathogenic mutations of $17 \alpha-\mathrm{OHD}$ and demonstrated their prevalence in Chinese Han and non-Chinese populations. We believe that genetic testing is of great clinical significance for these young patients with hypertension.

\section{Additional files}

Additional file 1: Shows materials and methods (DOCX $13 \mathrm{~kb}$ )
Additional file 2: 17a hydroxylase deficiency related mutations, and CYP17A1 protein three dimension structure pull graph in more detail (DOCX $299 \mathrm{~kb})$

\section{Abbreviations}

17a-OHD: 17a-hydroxylase deficiency; ARR: Aldosterone renin ratio; ASD: Androstenedione; BMl: Body mass index; $\mathrm{CAH}$ : Congenital adrenal hyperplasia; CYP17A1: Cytochrome P450 family 17 subfamily A member 1; DHEA: Dehydroepiandrosterone; DOC: Deoxycorticosterone; E2: Estradiol; FSH: Follicle-stimulating hormone; LH: Luteinizing hormone; MRI: Magnetic resonance imaging; PCR: Polymerase chain reaction; PROG: Progesterone;

TESTO: Testosterone

\section{Acknowledgments}

Many thanks to colleagues from the radiology department of Henan Provincial People's Hospital for providing the imaging data. We would also like to thank the medical director and staff of Bestnovo Beijing Medical Laboratory for their work in genetic testing and analysis.

\section{Authors' contributions}

MW was responsible for the collection of clinical cases and subsequent follow-up. MW, HW, HZ and LL were responsible for the diagnosis and treatment of the patients. MW, HW and FL both drafted and prepared the manuscript and data analysis and performed and reviewed the literature search on the topic. HW supervised and reviewed the manuscript as well as provided additional revisions. ML, FM and CF participated in the management of these patients. All authors read and approved the final manuscript.

Funding

Not applicable.

Availability of data and materials

We have put our supporting data in additional files. 
Ethics approval and consent to participate

Not applicable.

\section{Consent for publication}

Not applicable.

\section{Competing interests}

The authors declare that they have no competing interests.

\section{Author details}

'Department of Hypertension, Henan Provincial People's Hospital; People's Hospital of Zhengzhou University, Zhengzhou 450003, Henan, China. 2Bestnovo Beijing Medical Laboratory, No.14 Building, Room 502, PKUCare Industry Park, Zhong Guan Cun Life Science Park, Chang Ping District, Beijing, China.

Received: 10 November 2018 Accepted: 29 August 2019

Published online: 15 October 2019

\section{References}

1. Speiser PW, White PC. Congenital adrenal hyperplasia. N Engl J Med. 2003; 349:776-88.

2. White PC, New MI, Dupont B. Congenital adrenal hyperplasia. N Engl J Med. 1987:316:1519-24

3. Simard J, Durocher F, Mebarki F, et al. Molecular biology and genetics of the $3 \beta$-hydroxysteroid dehydrogenase/ $\Delta 5-\Delta 4$ isomerase gene family. J Endocrinol. 1996;150(Suppl):S189-207.

4. Singhellakis PN, Panidis D, Papadimas J, et al. Spontaneous sexual development and menarche in a female with 17a-hydroxylase deficiency. J Endocrinol Investig. 1986;9:177-83.

5. Bose HS, Sugawara T, Strauss JF 3rd, Miller WL. International congenital lipoid adrenal hyperplasia $C$ the pathophysiology and genetics of congenital lipoid adrenal hyperplasia. N Engl J Med. 1996;335:1870-8.

6. Auchus RJ. The genetics, pathophysiology, and management of human deficiencies of P450c17. Endocrinol Metab Clin N Am. 2001;30:101-19.

7. Costa-Santos M, Kater CE, Auchus RJ, Brazilian Congenital Adrenal Hyperplasia Multicenter Study Group. Two prevalent CYP17 mutations and genotype-phenotype correlations in 24 Brazilian patients with 17hydroxylase deficiency. J Clin Endocrinol Metab. 2004;89(1):49-60.

8. Kater CE, Biglieri EG. Disorders of steroid 17 alpha-hydroxylase deficiency. Endocrinol Metab Clin N Am. 1994;23:341-57.

9. Biglieri EG, Herron MA, Brust N. 17-hydroxylation deficiency in man. J Clin Invest. 1966;45(12):1946-54.

10. New MI. Male pseudohermaphroditism due to 17 alpha-hydroxylase deficiency. J Clin Invest. 1970;49(10):1930-41.

11. Chen $J$, Xu MY, Zhang DQ, et al. 17 alpha-hydroxylase deficiency —a case report. J Shanghai Second Med Univ. 1982;4:109-12.

12. Yanase T, Simpson ER, Waterman MR. 17-hydroxylase/17, 20-lyase deficiency from clinical investigation to molecular definition. Endocr Rev. 1991;12:91-108.

13. Picardo-Leonard J, Miller WL. Cloning and sequence of the human gene for P450C17 (steroid 17 alpha-hydroxylase/l7,20 lyase): Similarity with the gene for P450C21. DNA Cell Biol. 1987;6:439.

14. Fan YS, Sasi R, Lee C, et al. Localization of the human CYP17 gene (cytochrome P450(17 alpha)) to 10q24.3 by fluorescence in situ hybridization and simultaneous chromosome banding. Genomics. 1992;14:1110-1.

15. Sparkes RS, Klisak I, Miller WL. Regional mapping of genes encoding human steroidogenic enzymes: P450scc to 15q23-q24, adrenodoxin to 11q22; adrenodoxin reductase to 17q24-q25; and P450c17 to 10q24-q25. DNA Cell Biol. 1991:10:359-65.

16. Han B, et al. An unique exonic splicing mutation in the CYP17A1 gene as the cause of steroid 17a-hydroxylase deficiency. Chin J Endocrinol Metab. 2011;27:911-5

17. Hahm JR, Kim DR, Jeong DK, Chung JH, Lee MS, Min YK, Kim KW, Lee MK. A novel compound heterozygous mutation in the CYP17 (P450 17alphahydroxylase) gene leading to 17alpha-hydroxylase/17,20-lyase deficiency. Metabolism. 2003;52(4):488-92.

18. Sun SY, Bi YF, Liu JM, et al. A novel homozygous mutation (TAC/AA) at Condon 329 in CYP17A1 gene causes 17a-hydroxylase deficiency - case report and predegree study. Chin J Endocrinol. 2004;20(6):568-71.

19. Wei JQ, Wei JL, Li WC, et al. Genotyping of five Chinese patients with $17 \mathrm{a}$ hydroxylase deficiency diagnosed through high-performance liquid chromatography serum adrenal profile: identification of two novel CYP17 mutations. J Clin Endocrinol Metab. 2006:91:3647-53.

20. Tian Q, Yao F, Sha G, Huang S, Tseng H, Schindler AE. Genotyping of a Chinese family with 46,XX and 46,XY 17-hydroxylase deficiency. Gynecol Endocrinol. 2009;25(8):485-90.

21. Han B, Xue L, Fan M, Zhao S, Liu W, Zhu H, Cheng T, Lu Y, Cheng K, Song H, Liu Y, Qiao J. Clinical and molecular manifestation of fifteen 170HD patients: a novel mutation and a founder effect. Endocrine. 2016;53(3):784-90.

22. Yang J, Cui B, Sun S, Shi T, Zheng S, Bi Y, Liu J, Zhao Y, Chen J, Ning G, Li X. Phenotype-genotype correlation in eight Chinese 17alpha-hydroxylase/ 17,20 lyase-deficiency patients with five novel mutations of CYP17A1 gene. J Clin Endocrinol Metab. 2006;91(9):3619-25.

23. Biason-Lauber A, Kempken B, Werder E, Forest MG, Einaudi S, Ranke MB, Matsuo N, Brunelli V, Schonle EJ, Zachmann M. 17a-hydroxylase/17,20-lyase deficiency as a model to study enzymatic activity regulation: role of phosphorylation. J Clin Endocrinol Metab. 2000;85:1226-31.

24. Martin RM, Lin CJ, Costa EM, de Oliveira ML, Carrilho A, Villar H, Longui CA, Mendonca BB. P450c17 deficiency in Brazilian patients: biochemical diagnosis through progesterone levels confirmed by CYP17 genotyping. J Clin Endocrinol Metab. 2003:88:5739-46.

\section{Publisher's Note}

Springer Nature remains neutral with regard to jurisdictional claims in published maps and institutional affiliations.
Ready to submit your research? Choose BMC and benefit from:

- fast, convenient online submission

- thorough peer review by experienced researchers in your field

- rapid publication on acceptance

- support for research data, including large and complex data types

- gold Open Access which fosters wider collaboration and increased citations

- maximum visibility for your research: over $100 \mathrm{M}$ website views per year

At BMC, research is always in progress.

Learn more biomedcentral.com/submissions 